\title{
Pendapatan Desa Adat : Kontruksi Hukum Pungutan Untuk Mewujudkan Bebas Pungutan Liar
}

\author{
I Dewa Gede Herman Yudiawan'1
}

1Program Pascasarjana, Universitas Pendidikan Ganesha, Email : dewa.herman18@gmail.com

\begin{tabular}{l}
\hline Info Artikel \\
\hline Masuk: 12 Pebruari 2019 \\
Diterima: 26 Juli 2019 \\
Terbit: 31 Juli 2019 \\
Keywords: \\
Urgenc; Levy by Pakraman \\
Vilage; Village Income; Illegal \\
Levy \\
\\
\\
\\
Corresponding Author: \\
I Dewa Gede Herman \\
1udiawan, email: \\
dewa.herman18@gmail.com \\
p08 \\
10.24843/JMHU.2019.v08.i02. \\
Kata kunci: \\
Urgensi; Pungutan Oleh Desa \\
Punaman; Pendapatan Desa; \\
\end{tabular}

\begin{abstract}
The Bali Province Regulation No. 32001 Article 10 paragraph (1) stated that village income is one of the other legitimate income. In the article there is uncertainty in the meaning of Article 10 paragraph (1) letter e, because in the explanation clause there is no further explanation about "other legitimate income". Traditional villages use natural resources in their area such as tourist areas as village income. In the Presidential Regulation No. 87 of 2016 about the Illegal Levy Eradication Task Force, the levies carried out by Pakraman village against retribution to tourist areas are categorized as illegal levies by the task force teams as happened at the sunrise beach. This study aims to understand and explore the legal protection within the levies carried out on tourism objects and the urgency of the legal protection for Pakraman village to collect retribution from tourist attractions in the area of Pakraman village or adat village. This study used normative legal research methods. The results of this study are based on Act No. 28 of 2009 concerning Regional Taxes and Regional Retributions, stated that for tourist area entrance fees are regulated in Article 127 (i), which should be managed by the regional government,_because it is a statutory mandate.. For example 2 tourist attractions, Tanah Lot in Tabanan and Taman Ayun in Badung. This management model is needed by the government and Pakraman village to avoid indications of extortion. The urgency of the legal regulation here is very much needed by Adat village.
\end{abstract}

\begin{tabular}{l} 
Abstrak \\
\hline Dalam Perda Provinsi Bali No 32001 Pasal 10 ayat (1) telah \\
disebutkan bahwa pendapatan desa salah satunya adalah \\
pendapatan lainnya yang sah. Dalam pasal tersebut terjadi \\
ketidakjelasan makna dalam Pasal 10 ayat (1) huruf e, karena \\
dilihat dalam penjelasannya tidak ada penjelasan lebih lanjut \\
dengan apa yang dinamakan pendapatan lain yang sah. Desa \\
adat memanfaatkan sumber daya alam yang ada di daerahnya \\
seperti kawasan wisata sebagai pendapatan desa. Dalam \\
Peraturan presiden No 87 tahun 2016 tentang Satuan Tugas \\
Sapu Bersih Dan Pungutan Liar, pungutan yang dilakukan oleh \\
desa Pakraman terhadap retribusi masuk kawasan wisata \\
dikategorikan sebagai pungutan liar oleh tim saber pungli seperti \\
yang terjadi di pantai matahari terbit.Penelitian ini bertujuan \\
untuk memahami dan mendalami payung hukum dalam \\
pungutan yang dilakukan pada obyek pariwisata dan urgensi \\
dari payung hukum bagi desa Pakraman untuk melakukan \\
pemungutan retribusi masuk kawasan obyek wisata yang ada di
\end{tabular}




\begin{abstract}
kawasan desa Pakraman atau desa adat. Penelitian ini mengunakan metode penelitian hukum normatif. Hasil dari penelitian ini adalah dilihat dari Undang - Undang Nomor 28 Tahun 2009 tentang Pajak Daerah dan Retribusi Daerah bahwa untuk pungutan masuk kawasan wisata sudah diatur dalam Pasal 127 huruf $i$, yang seharusnya dikelola oleh pemerintah daerah karena merupakan mandat peraturan perundangundangan. Mengambil contoh 2 tempat wisata yaitu Tanah Lot yang ada di Kabupaten Tabanan dan Taman Ayun yang berada di wilayah Kabupaten Badung. Model pengelolaan seperti ini lah yang diperlukan oleh pemerintah dan desa Pakraman untuk menghindari indikasi Pungli. Urgensi payung hukum disini sangat diperlukan oleh desa adat.
\end{abstract}

\title{
I. Pendahuluan
}

Dalam penyelenggaraan sistem Pemerintahan Negara Kesatuan Republik Indonesia (NKRI) keberadaan desa merupakan keberadaan sangat penting dalam menjalankan pemerintahan dalam sistem pemerintahan di Indonesia. Penyelenggaraan pemerintahan Desa dengan kualitas yang baik berpotensi menggenjot kesejahteraan bagi masyarakat Desa, sekaligus dapat meningkatkan kualitas hidup masyarakat dari berbagai kondisi di Desa. ${ }^{1}$ Kedudukan Desa kini telah diakui dengan Undang - Undang Nomor 6 tahun 2014 tentang Desa (Selanjutnya disebut dengan UU desa). Yang menjadi tonggak baru dalam menjalankan pemrintahan Desa. Desa seperti yang dijelaskan dalam UU desa, desa merupakan kumpulan masyarakat hukum yang dimana mereka telah memiliki batas wilayah yang berwenang untuk mengatur dan mengurus urusan dalam pemerintahan, kepentingan bersama masyarakat setempat berdasarkan prakarsa masyarakat, hak asal usul, dan/atau hak tradisional yang telah mendapat pengakuan dan dihormati dalam sistem pemerintahan Negara Kesatuan Republik Indonesia. Dalam UU desa, terdapat dua jenis desa yang diakui dalam UU tersebut terdiri atas desa dan desa adat seperti apa yang dijelaskan dalam Pasal 6. Dalam desa adat tentunya mempunyai peraturan adat yang mengatur tata tertib masyarakat dalam kawasan desa adat tersebut. Dalam UU desa hal ini telah diatur dalam UU desa Pasal 110 mengatur bahwa Peraturan Desa Adat diselaraskan dengan aturan hukum adat dan norma adat istiadat yang telah hidup dan berlaku di Desa Adat sepanjang tidak bertentangan dengan berbagai ketentuan peraturan perundang-undangan yang ada.

Bali, pulau kecil yang ada di salah satu dari seluruh pulau di Indonesia merupakan salah satu provinsi yang sangat unik dengan berbagai kebudayaan dan adat istiadat yang masih melekat penuh pada masyarakatnya dan juga terkenal di seluruh dunia karna menawarkan pariwisata yang sangat menarik sehingga banyak wisatawan mancanegara datang ke Bali untuk menyaksikan keindahan alam dan adat istiadat yang ada di Bali. Di Bali, terdapat dua jenis desa yang hidup secara berdampingan dan sejalan harmonis tanpa gesekan satu sama lain, yaitu desa dinas (administrasi) dan Desa Pakraman atau juga dapat disebut desa adat. Desa adat dengan kata lain sebagai desa dresta adalah kumpulan masyarakat hukum adat di Provinsi Bali yang telah mempunyai satu kesatuan yang tumbuh dengan baik dalam bidang tradisi dan tata karma pergaulan hidup dalam masyarakat umat Hindu secara turun-temurun dalam ikatan Kayangan Tiga atau Kayangan Desa, yang diamana telah

\footnotetext{
1 Sutrisno P. Mulyono. 2014. Sinergitas Penyelenggaraan Pemerintahan Desa Pasca Pemberlakuan UU No. 6 Tahun 2014 Tentang Desa.Masalah-Masalah Hukum, 43(3), h. 438.
} 
memiliki wilayah tertentu serta berhak mengurus rumah tangganya sendiri. ${ }^{2}$ Desa dinas berwenang mengatur hal-hal yang bersifat administrasi kenegaraan dan desa adat lebih merujuk pada hal-hal yang bersifat keagamaan dan budaya. ${ }^{3}$

Dalam menjalankan organisasi atau pemerintahan Desa Adat/Pakraman di Bali tentunya memerlukan biaya yang tidak sedikit dan bersifat terus menerus. Maka dari itu desa adat memanfaatkan sumber daya alam yang ada di daerahnya seperti kawasan wisata. Dengan keputusan Desa Pakraman atau yang dikenal dengan perarem, Desa Pakraman melakukan pungutan retribusi terhadap wisatawan yang masuk ke area wisata yang ada di Desa Pakraman. Seperti yang dilakukan oleh Desa Pakraman Sanur Kaja, yang melakukan pungutan masuk ke wilayah wisata pantai matahari terbit. Seiring berjalannya waktu bahwa banyaknya terjadi pungutan liar, mendapat perhatian yang serius oleh Presiden melalui Peraturan presiden No 87 tahun 2016 tentang satuan tugas sapu bersih dan pungutan liar. Pungutan yang dilakukan oleh Desa Pakraman n ini dikategorikan sebagai pungutan liar oleh tim saber pungli yang menyebabkan dilakukannya OTT terhadap petugas Desa Pakraman yang sedang bertugas di pantai matahari terbit. Menurut bendesa sanur kaja, "Itu masuk kawasan wisata palemahan Desa Pakraman. Bukan parkir, itu kawasan masuk wisata, Sanur berhak atas palemahannya, mana ada tulisan parkir. Ijin Pemda memang tidak ada semua, ini berdasarkan awig dan pararem, keputusan paruman agung namanya bersama tokoh-tokoh adat" 4 . Dalam Peraturan Daerah Provinsi Bali No. 3 Tahun 2001 tentang Desa Pakraman (yang selanjutnya disebut Perda Provinsi Bali tentang Desa Pakraman No 3 2001) yang telah mengalami perubahan dengan Peraturan Daerah Provinsi Bali No 3 Tahun 2003 tentang Perubahan Atas Peraturan Provisi Bali Nomor 3 Tahun 2001 Tentang Desa Pakraman. Dalam Perda Provinsi Bali tentang Desa Pakraman No 32001 Pasal 10 ayat (1) telah disebutkan bahwa pendapatan desa sebagai berikut :

Pendapatan Desa Pakraman didapatkan dari :

a. urunan krama Desa Pakraman; (seperti iuran kepada masyarakat desa)

b. hasil pengelolaan kekayaan desa pakraman; (seperti penghasilan dari sawah milik desa)

c. kegiatan hasil usaha lembaga perkreditan desa (LPD); (keuntungan dari LPD)

d. bantuan pemerintah dan pemerintah daerah; (bansos dari pemerintah)

e. pendapatan lainnya yang sah;

f. sumbangan pihak ketiga yang tidak mengikat. (seperti sedekah dari warga luar Desa Pakraman)

Dapat dilihat dalam pasal tersebut terjadi ketidakjelasan dalam Pasal 10 ayat (1) huruf e Perda Provinsi Bali tentang Desa Pakraman No 3 2001, karena dilihat dalam penjelasannya tidak ada penjelasan lebih lanjut dengan apa yang dinamakan pendapatan lain yang sah. Tidak adanya kejelasan dari Perda Provinsi Bali tentang Desa Pakraman No 32001 Pasal 10 ayat (1) huruf e yang mengatur tentang pendapatan lainnya yang sah oleh Desa Pakraman yang bersumber dari retribusi masuk obyek wisata yang ada dalam Desa Pakraman. Di sini dapat ditemukan bahwa terjadi kekosongan hukum tentang pungutan retribusi masuk

2 Wayan P Windia, 2010, Bali Mawacara kesatuan Awig - awig, Hukum dan Pemerintahan di Bali, Denpasar: Udayana University Press, h. 8.

${ }^{3}$ I Ketut Teguh Yudha Satrya, et. Al., 2017. Sinergi Desa Adat dan Desa Dinas Dalam Pengelolaan Aset Desa Untuk Mewujudkan Harmonisasi (Studi Pada Desa Adat dan Desa Dinas Sambangan). JIMAT (Jurnal Ilmiah Mahasiswa Akuntansi) Undiksha, 7(1). h.2.

${ }^{4}$ Putu Supartika, 2018, bali.tribunnews.com. Bendesa Sanur Kaja Beri Klarifikasi, yang Ditangkap di Pantai Matahari Terbit Bukan Pecalang, Retrieved from https:// bali.tribunnews.com/2018/11/07/ bendesa-sanur-kaja-beri-klarifikasi-yang-ditangkap-dipantai-matahari-terbit-bukan-pecalang . 
obyek wisata yang ada di dalam Desa Pakraman sebagai pendapatan Desa Pakraman yang menjadi menarik untuk dibahas lebih lanjut. Sehingga permasalahan yang dapat ditarik dari permasalahan ini adalah apakah pungutan yang dilakukan oleh Desa Pakraman telah memiliki payung hukum, terutama pungutan yang dilakukan pada obyek pariwisata dan bagaimana konstruksi dari payung hukum yang diperlukan oleh Desa Pakraman dalam hal pemungutan retribusi masuk kawasan obyek wisata.

Penelitian ini bertujuan untuk mengetahui konstruksi dari payung hukum dalam pungutan yang dilakukan pada obyek pariwisata dan urgensi dari payung hukum bagi Desa Pakraman untuk melakukan pemungutan retribusi masuk kawasan obyek wisata yang ada di kawasan Desa Pakraman atau Desa Adat.

Beberapa penelitian sebelumnya yang meneliti persoalan yang hampir sama dengan peneliti lakukan diantaranya; I Gusti A. A. Ariani dan Ni Nym Sukerti, pada tahun 2014 melakukan penelitian tentang eksistensi otonomi Desa Pakraman di Bali dalam kerangka otonomi daerah khususnya dalam pengelolaan obyek wisata. Kemudian Wahyudi Arimbawa, dan I Komang Gede Santhyasa pada tahun 2017 melakukan penelitian tentang model pengelolaan obyek wisata peninggalan sejarah taman ayun berbasis nilai lokal. Dilihat secara umu bahwa kedua penelitian tersebut memiliki obyek yang sama yaitu mengenai pengelolaan obyek wisata, namun mempunyai fokus yang berbeda. Dari kedua penelitian di atas memiliki perbedaan yang mendasar karena berfokus pada pungutan desa sebagai pendapatan Desa Pakraman di Bali, payung hukum pungutan pada obyek pariwisata oleh Desa Pakraman dan urgensi payung hukum oleh Desa Pakraman dalam melakukan pungutan retribusi masuk obyek pariwisata.

\section{Metode Penelitian}

Menganalisa dan mengkaji atas kekaburan hukum dalam pemungutan retribusi masuk kawasan obyek wisata yang ada di kawasan Desa Pakraman oleh Desa Pakraman sendiri di Bali sebagai pendapatan lainnya yang sah atau resmi, seperti yang diatur atau ditegaskan dalam Pasal 10 ayat (1) huruf e yang menyebabkan timbulnya OTT terhadap petugas Desa Pakraman yang sedang bertugas untuk memungut retribusi masuk kawasan wisata di Desa Pakraman maka metode penelitian yang digunakan dalam penulisan penelitian ini adalah metode penelitian hukum normatif, dengan menganalisa kekaburan norma dari suatu peraturan perundang - undangan.

Adapun pendekatan-pendekatan yang digunakan dalam penelitian ini adalah pendekatan perundang-undangan (The Statue Approach), dan pendekatan konseptual. Dalam penelitian hukum normatif penggunaan metode pendekatan perundang-undangan dimana peneliti sangat perlu memahami dari hierarki dan Asas-Asas dalam peraturan perundangundangan. ${ }^{5}$ Pendekatan konseptual (conceptual approach) sudah lazim digunakan bagi peneliti untuk menguraikan dan menganalisis permasalahan dari penelitian yang beranjak dengan adanya norma kosong. ${ }^{6}$

Bahan hukum yang nantinya digunakan sebagai bahan dalam melakukan penelitian ini adalah bersumber dari peraturan perundang-undangan atau yang biasa disebut dengan bahan hukum primer serta bahan hukum sekunder, yaitu dengan meneliti peraturan perundang-undangan dan buku yang terkait dengan penelitian ini. Kemudian terakhir bahan hukum tertier, yaitu bahan hukum yang memberikan petunjuk maupun kejelasan

\footnotetext{
${ }_{5}^{5}$ Peter Mahmud Marzuki, 2005, Penelitian Hukum, Prenadamedia Group, Jakarta, h. 137.

${ }^{6}$ I Made. Pasek Diantha. 2017. Metodelogi Penelitian Hukum Normatif. Jakarta: Prenada Media Group, h. 159.
} 
terhadap bahan hukum primer dan bahan hukum sekunder. Kemudian sumber-sumber hukum tersebut dikumpulkan dengan teknik bola salju dan dianalisis menggunakan teknik argumentatif.

\section{Hasil dan Pembahasan}

\subsection{Payung Hukum Pungutan Pada Obyek Pariwisata Oleh Desa Pakraman}

Pulau Bali merupakan pulau yang sudah terkenal ke seluruh pelosok dunia dengan pariwisatanya yang masih sangat asri dan tentunya tiada duanya di seluruh dunia sehingga banyak wisatawan dari berbagai dunia datang berduyun-duyun untuk menyaksikan dan menikmati secara langsung keindahan alam yang ada di Bali. Masyarakatnya juga yang sangat ramah menjadikan Bali sangat nyaman di mata para wisatawan. Kehidupan masyarakat yang masih sangat kental menerapkan adat-istiadat yang telah turun-temurun dijalankan dan dipatuhi menjadikan tidak ada seorang pun untuk melanggarnya. Seperti pelaksanaan upacara agama yang masih dijalankan dengan cara tradisional di tengah modernisasi jaman yang tengah terjadi menjadi cermin kuatnya adat di Bali.

Tentunya dalam menjalankan semua aktifitas adatnya tersebut tentunya memerlukan biaya yang tidak sedikit. Para tokoh masyarakat adatpun mencari jalan untuk menanggulangi hal tersebut karena jika ini dibebankan secara penuh kepada masyarakat akan sangat membebani masyarakat sendiri di tengah tuntutan kehidupan yang kian meningkat, maka seperti yang dilakukan masyarakat Sanur yang memanfaatkan potensi alam yang ada di kawasan desanya untuk dijadikan salah satu cara untuk memperoleh pemasukan yang nantinya akan digunakan untuk pemenuhan pembiayaan dalam penyelenggaraan kegiatan yang bersifat adat sehingga dapat mengurangi beban dari masyarakat itu sendiri. Melalui paruman yang telah disetujui oleh semua masyarakat maka masyarakat Sanur bersepakat untuk melakukan pungutan retribusi masuk kawasan wisata yang ada di desa Sanur. Paruman merupakan rapat atau peradilan adat dimana hasil dari paruman tersebut dinamakan perarem. Pararem adalah keputusan yang lahir paruman Desa Pakraman atau desa adat yang memiliki kekuatan hukum mengikat setara kuatnya dengan awig-awig.7

Dilihat dalam Pasal 2 Ayat (1) Undang-undang Nomor 28 Tahun 2009 tentang Pajak Daerah dan Retribusi Daerah (selanjutnya disebut dengan UU pajak daerah dan retribusi daerah Nomor 28 Tahun 2009), yang termasuk pajak provinsi terdiri atas ; pajak kendaraan bermotor, bahan bakar kendaraan bermotor, air permukaan, rokok, dan bea balik nama kendaraan bermotor. Selain pajak provinsi, kabupaten/kota tentunya juga mempunyai hak untuk memungut pajak sebagai pemasukan pemerintah kabupaten/kota yang nantinya akan digunakan untuk menjalankan roda pemerintahan. Untuk pajak yang dapat dipungut oleh pemerintah Kabupaten/Kota, berdasarkan Pasal 2 Ayat (2) UU pajak daerah dan retribusi daerah Nomor 28 Tahun 2009 Terdiri atas ; pajak hotel, restoran, hiburan, reklame, penerangan jalan, mineral bukan logam dan batuan, parkir, air tanah, sarang burung walet, bumi dan bangunan perdesaan dan perkotaan, dan yang terakhir bea perolehan hak atas tanah dan bangunan.

Untuk retribusi dalam UU pajak daerah dan retribusi daerah, dalam Pasal 108 diatur mengenai obyek dari retribusi itu sendiri yang terdiri dari 3 retribusi yaitu retribusi jasa umum, retribusi jasa usaha, dan retribusi perizinan tertentu. Yang termasuk kedalam jenis dari retribusi jasa umum berdasarkan Pasal 110 ayat (1) UU pajak daerah dan retribusi

\footnotetext{
${ }^{7}$ Sudantra, I. K., Astiti, T. I. P., \& Laksana, I. G. N. D., 2017. Sistem peradilan adat dalam kesatuankesatuan masyarakat hukum adat desa pakraman di Bali. Jurnal Kajian Bali (Journal of Bali Studies),7(1), h. 94.
} 
daerah Nomor 28 Tahun 2009 terdiri dari ; retribusi dalam bidang pelayanan kesehatan, persampahan ataupun kebersihan, penggantian biaya mencetak kartu tanda penduduk (KTP) dan akta catatan sipil, pelayanan dalam bidang pemakaman dan pengabuan mayat, parkir kendaraan di tepi jalan umum, pasar, pengujian kendaraan bermotor, pemeriksaan alat pemadaman kebakaran, pengganti biaya cetak peta, penyediaan ataupun penyedotan kakus, pengolahan limbah cair, pelayanan tera atau tera ulang, pelayanan pendidikan, dan yang terakhir pengendalian menara untuk telekomunikasi.

Retribusi jasa usaha dalam UU pajak daerah dan retribusi daerah, diatur dalam Pasal 127 UU pajak daerah dan retribusi daerah Nomor 28 Tahun 2009 yang mengatur mengenai jenis dari retribusi jasa usaha itu sendiri jasa adapun jenis dari retribusi jasa usaha adalah sebagai berikut; retribusi bidang pemakaian kekayaan daerah, pasar grosir atau bida juga dikategorikan dengan pertokoan, tempat pelelangan, terminal, tempat khusus parkir kendaraan, tempat penginapan, rumah potong hewan, pelayanan ke pelabuhan, tempat rekreasi dan olahraga, penyeberangan di air, terakhir penjualan produksi usaha daerah.

Melihat tentang retribusi kawasan wisata, dalam UU pajak daerah dan retribusi daerah Nomor 28 Tahun 2009, terdapat pada Retribusi dari Tempat Rekreasi dan Olahraga. Dilihat lebih lanjut bahwa obyek Retribusi Tempat Rekreasi dan Olahraga adalah salah satunya pelayanan tempat pariwisata, hal ini diatur dalam Pasal 136 UU pajak daerah dan retribusi daerah Nomor 28 Tahun 2009. Dapat dilihat di sini bahwa kewenangan untuk melakukan pungutan terhadap retribusi masuk kawasan wisata dimana pemerintah daerah telah mendapat mandat dari UU pajak daerah dan retribusi daerah Nomor 28 Tahun 2009 yang tentunya desa adat tidak bisa mengambil alih wewenang dari pemerintah daerah untung melakukan pungutan. Untuk objek retribusi perizinan tertentu tentunya merupakan retribusi terhadap izin tertentu saja yang mungkin perlu untuk mendapat pengawasan oleh pemerintah karena jika tidak mendapat pengawasan ditakutkan akan terjadinya dampak yang dapat merugikan masyarakat.

Dilihat lebih lanjut dari UU pajak daerah dan retribusi daerah Nomor 28 Tahun 2009 secara tegas mengatur untuk pungutan masuk kawasan wisata sudah diatur dalam Pasal 127 huruf i UU pajak daerah dan retribusi daerah Nomor 28 Tahun 2009, yang seharusnya dikelola oleh pemerintah daerah. Namun seperti di pantai sanur, bahwa pengelolaan tidak ada kejelasan bagi desa adat atau Desa Pakraman di Bali yang melakukan pungutan tersebut dengan tujuan untuk menambah pemasukan desa adat yang digunakan nantinya untuk kegiatan adat atau kegiatan keagamaan di Desa Pakraman. Pada Perda Provinsi Bali No 3 2001, dalam Pasal 1 angka 4 mengatur bahwa Desa pakraman merupakan tradisi serta tata karma masyarakat beragama Hindu di propinsi Bali dalam ikatan kahyangan tiga atau kahyangan desa, yang mempunyai kekayaan sendiri serta berhak mengurusnya sendiri. Artinya di sini Desa Pakraman yang ada di provinsi Bali yang terdiri dari umat beragama Hindu sudah ada dari jaman dahulu dan masih bertahan degan kuat sampai sekarang dan terus dapat mempertahankan tradisinya. Hal ini menunjukkan bahwa keberadaan Desa Pakraman adalah desa sebagai wadah atau tempat aktivitas bagi umat Hindu di daerah ini yang dalam hal ini khususnya di provinsi Bali. ${ }^{8}$

Diklasifikasikan bahwa ada 3 jenis Desa Pakraman di Bali. Pertama Desa Bali Aga (Bali Mula), yaitu merupakan desa dengan keadaan masih asli dengan tradisi Bali tanpa adanya pengaruh tradisi maupun kebudayaan lain. Masa yang sebelum adanya pengaruh agama Hindu sampai datangnya pengaruh agama Hindu yang dibawa dari kerajaan Majapahit

8 Adharinali. 2012. Eksistensi Hukum Adat Dalam Penyelenggaraan Pemerintahan Desa Di Bali. Jurnal Rechts Vinding: Media Pembinaan Hukum Nasional, 1(3), h. 413. 
pada masa itu. ${ }^{9}$ Kedua Desa Apanage(Bali Dataran), adalah dimana pada saat atau jaman tersebut telah adanya pengaruh luar, yang mempengaruhi tradisi maupun kebudayaan masyarakat Bali asli pada masa itu desa pada jaman telah dipengaruhi serta mengikuti tradisi dari hukum Hindu yang bersumber dari kitab Manawadharmasastra yang sebelumnya telah diterapkan pada kerajaan Majapahit. ${ }^{10}$ Ketiga Desa Anyar (desa baru), merupakan desa yang baru terbentuk yang merupakan adanya perpindahan penduduk dari beberapa daerah ke dalam satu daerah dan membuka sebuah desa yang mereka beri nama sistem kemasyarakatan yang mereka tentukan sendiri. Sebagai efek yang secara tidak langsung ditimbulkan dengan adanya perpindahan penduduk lokal (transmigrasi lokal) dengan tujuan awal ialah untuk mencari penghidupan baru dengan harapan kehidupan yang lebih baik. ${ }^{11}$

Desa adat atau pakraman tentunya memiliki tugas dan wewenang untuk dapat menjalankan kehidupan masyarakat adat. Seperti apa yang telah disebutkan dalam UU desa sebagai pedoman bagi desa telah diatur mengenai kewenangan desa adat yang ditetapkan Pasal 103 UU desa. Kewenangan desa adat atau pakraman tentunya tidak Cuma satu kewenangan, melainkan ada beberapa kewenangan yang telah ditetapkan sebagai kewenangan desa adat atau Desa Pakraman yang terdiri dari ; mengatur serta melaksanakan pemerintahan yang berdasarkan susunan asli, pengurusan wilayah yang menjadi kewenangan adat, melestarikan nilai sosial budaya dalam desa adat, penyelesaian perselisihan yang terjadi yang dilandaskan kepada hukum adat di desa adat yang telah selaras dengan prinsip-prinsip HAM dengan pemufakatan, sidang perdamaian dengan peradilan desa adat dimana yang telah sesuai dengan ketentuan peraturan perundangundangan yang berlaku, memelihara rasa ketentraman dan ketertiban di dalam masyarakat desa adat, pengembangan kehidupan hukum adat sesuai dengan kondisi sosial budaya masyarakat desa.

Desa pakraman di Bali telah memiliki tugas yang telah diatur dalam Perda Provinsi Bali No 32001 Pasal 5 terdapat beberapa tugas yang dipunyai dan wajib dijalankan oleh desa pakraman.

Desa pakraman di Bali mempunyai tugas sebagai berikut; membuat awig-awig (aturan adat) atau aturan Desa Pakraman, mengurus karma atau masyarakat desa, mengelola harta kekayaan desa, melaksanakan kegiatan pembangunan bersama pemerintah dalam segala bidang dengan berprioritas pada bidang (keagamaan, kebudayaan, kemasyarakatan), pengembangan nilai kebudayaan Bali dan mengembangkan kebudayaan yang bersifat nasional pada umumnya dan kebudayaan daerah Bali pada khususnya berdasarkan prisip (paras-paros,sagilik-saguluk,salunglung-sabayantaka), melindungi krama atau masyarakat desa.

Tentunya Desa Pakraman / adat di Bali juga memiliki kewenangan dalam menjalankan roda kehidupan masyarakat desa yang masih sangat kuat secara adat-istiadat dan kebiasaan di Desa Pakraman, wewenang oleh Desa Pakraman diatur dalam Pasal 6 Perda Provinsi Bali No 32001 ada beberapa wewenang oleh Desa Pakraman yang dapat di jabarkan berikut ini ;menyelesaikan perselisihan adat dan agama di dalam Desa Pakraman dengan tetap mengedepankan kerukunan masyarakat dan toleransi antar krama desa atau masyarakat desa dengan awig-awig serta adat kebiasaan di Desa Pakraman, mengambil keputusan

\footnotetext{
${ }^{9}$ I Wayan Gede Suacana, 2016, , Tantangan Dan Peluang Otonomi Desa Dalam Membangun Governance Desa Di Bali, Jurnal Ilmu Politik, 22(1), h. 113.

${ }^{10}$ Ibid.

11 Ibid, h. 114.
} 
untuk melaksanakan pembangunan di Desa Pakraman, terutama yang berkaitan dengan Tri Hita Karana, melakukan tingkah-laku hukum baik di dalam maupun di luar Desa Pakraman.

Tentunya dalam menjalankan tugas dan wewenang oleh Desa Pakraman memerlukan biaya yang bersumber dari pendapatan Desa Pakraman. Seperti apa yang telah disebutkan tentang pendapatan Desa Pakraman, pendapatan tersebut telah diatur dan sebutkan sebelumnya. Seperti apa yang kemudian diatur dalam Pasal 10 ayat (2) Perda Provinsi Bali No 32001 bahwa pendapatan Desa Pakraman digunakan untuk memenuhi kebutuhan pembangunan dan penyelenggaraan kegiatan di Desa Pakraman. Diperjelas kembali dalam penjelasannya bahwa pendapatan Desa Pakraman nantinya dipergunakan untuk biaya ; ketatausahaan dan sangkep (rapat) prajuru (pemimpin) desa serta paruman (rapat besar) krama (masyarakat) desa, membangun di bidang mental spiritual, pembinaan untuk membantu pengembangan usaha - usaha masyarakat Desa Pakraman, serta membantu pembangunan di Desa Pakraman.

Jelas sudah ke mana arah dari pendapatan Desa Pakraman dipergunakan untuk kebutuhan Desa Pakraman dan diharapkan dapat mengurangi beban masyarakat. Namun melihat dari sumber pendapatan Desa Pakraman seperti yang telah disebutkan dalam Perda Provinsi Bali No 32001 tentunya masih merasa kurang oleh Desa Pakraman. Sehingga seperti apa yang dilakukan Desa Pakraman sanur dengan melakukan pungutan masuk kawasan wisata yang ada di Desa Pakraman sanur yang berdasarkan perarem. Dilihat pada UU pajak daerah dan retribusi daerah Nomor 28 Tahun 2009 bahwa untuk retribusi masuk kawasan wisata sudah diatur dalam Pasal 127 huruf i UU pajak daerah dan retribusi daerah Nomor 28 Tahun 2009 dan dalam pengelolaannya terjadi ketidakjelasan peraturan daerah yang mengatur atau menyebutkan bahwa desa adat atau Desa Pakraman dapat melakukan pungutan masuk kawasan wisata yang ada di wilayah Desa Pakraman sebagai pendapatan desa, sehingga dapat dikatakan payung hukum dari pungutan yang dilakukan oleh Desa Pakraman belum ada yang mengatur secara jelas baik dalam UU pajak daerah dan retribusi daerah Nomor 28 Tahun 2009 maupun dalam Perda Provinsi Bali No 32001.

\subsection{Konstruksi Payung Hukum Oleh Desa Pakraman Dalam Pungutan Retribusi Masuk Kawasan Obyek Wisata}

Sebelum tahun 2004, setiap permasalahan dan tantangan yang terjadi di Desa Pakraman dihadapi sendiri-sendiri oleh Desa Pakraman yang bersangkutan dengan berlandaskan kepada otonomi yang dimilikinya. ${ }^{12}$ Untuk menyelesaikan masalah-masalah yang ada di desa khususnya Desa Pakraman, maka berdasarkan pada Perda Provinsi Bali tentang Desa Pakraman No 32001 dibentuk lah Majelis Desa Pakraman (MDP) yang diharapkan untuk menyelesaikan berbagai permasalahan yang ada pada semua Desa Pakraman yang baru biasa dibentuk pada tahun 2004.

Desa Pakraman tentunya telah hak yang dinamakan hak otonomi semenjak Desa Pakraman tersebut terbentuk. Wirtha Griadhi menyatakan bahwa terdapat 3 kekuasaan dalam menjalankan otonomi, yaitu :

a. Kekuasaan untuk menetapkan berbagai aturan-aturan hukum yang tentunya berlaku bagi mereka.

b. Kekuasaan untuk penyelenggaraan kehidupan dalam organisasinya.

12 Dewa Nyoman Gede Suatmaja, 2006, Peranan Majelis Desa Pakraman Bali Dalam Pelaksanaan Investasi Kepariwisataan Di Wilayah Desa Pakraman. Jurnal Magister Hukum Udayana (Udayana Master Law Journal), 5(2), h. 356. 
c. Kekuasaan untuk menyelesaikan permasalahan hukum. ${ }^{13}$

Desa pakraman di Bali yang berjalan berlandaskan pada ajaran Tri Hita Karana. Ajaran Tri Hita Karana merupakan tiga sumber penyebab terjadinya sebuah kesejahteraan dan kebahagiaan di dalam semua kehidupan makhluk hidup ciptaan Tuhan yang berada di dunia. Hubungan tersebut meliputi: (1) hubungan antara manusia dengan sang pencipta yaitu Tuhan Yang Maha Esa; (2) hubungan antara manusia dengan sesamanya yang dalam hal ini dimaksud adalah hubungan manusia dengan sesame manusia ;dan (3) hubungan antara manusia dengan alam sekitarnya atau lingkungan dari manusia itu sendiri. ${ }^{14}$ Untuk pungutan masuk kawasan wisata yang ada di wilayah Desa Pakraman oleh Desa Pakraman man yang dikategorikan sebagai pendapatan desa, yang dimana Desa Pakraman di Bali selama ini diatur dalam hukum positif melalui Perda Provinsi Bali tentang Desa Pakraman No 32001 yang telah direvisi dengan Peraturan Daerah Provinsi Bali No 3 Tahun 2003. Dalam kedua Perda tersebut belum ada yang aturan yang menegaskan tentang pungutan masuk kawasan wisata di Desa Pakraman yang menjadi pendapatan Desa Pakraman yang melindungi Desa Pakraman dari pungutan liar yang selama ini telah gencar ditertibkan oleh pemerintah.

Dalam hal ini untuk menanggulangi indikasi terjadinya pungutan liar oleh Desa Pakraman dalam pemungutan retribusi masuk kawasan wisata yaitu dengan melakukan kerja sama dengan pihak pemerintah daerah. Hal ini tentu saja dapat dilakukan berdasarkan Peraturan Pemerintah No 50 Tahun 2007 tentang Tata Cara Pelaksanaan Kerja sama Daerah (selanjutnya disebut PP No 50 th 2007). Dalam Pasal 2 huruf c disebutkan bahwa penyelenggaraan kerjasama daerah yang dilakukan dengan berlandaskan pada prinsip sinergi. Yang dimaksud dengan prinsip "sinergi" sesuai dengan penjelasan PP No 50 th 2007 adalah upaya untuk mencapai sebuah keharmonisan antara pemerintah, masyarakat dan swasta untuk menjalin sebuah kerja sama demi tercapainya keharmonisan dan kesejahteraan dalam kehidupan masyarakat. Hal ini juga didukung dengan Peraturan Daerah Provinsi Bali Nomor 2 Tahun 2012 Tentang Kepariwisataan Budaya Bali. Yaitu dalam Pasal 25 memperbolehkan terjadinya sebuah kerja sama antara pemerintah daerah dengan Desa Pakraman agar mencegah terjadinya aktivitas kepariwisataan yang tidak sejalan dengan konsep kebudayaan yang ada di Bali. Hal ini juga telah dilakukan sebelumnya oleh Pemerintah Daerah Kabupaten Tabanan dengan Desa Pakraman Beraban dalam bidang pengelolaan obyek wisata yang ada di Beraban yaitu Tanah Lot. Melalui Surat Perjanjian No. 12 Tahun 2011 dan Nomor 358/DPBRB/XI/2011, tentang Pengelolaan Daya Tarik Wisata Tanah Lot. ${ }^{15}$ Tentunya dengan adanya perjanjian kerja sama maka akan berdampak juga kepada pembagian hasil oleh pemerintah dengan Desa Pakraman.

Mengenai pelaksana pengelolaan Kawasan Luar Pura Taman Ayun ini diatur dengan Keputusan Bupati Badung No. 2038/02/HK/2012 Tentang Penetapan Pelaksana Pengelolaan ODTW Kawasan Luar Pura Taman Ayun di Kab. Badung Oleh Puri Ageng Mengwi (manajemen keluarga). ${ }^{16}$ Di sini terlihat sangat jelas bahwa pengelolaan Kawasan

13 A.A I. A. Atu Dewi. 2014, Eksistensi Otonomi Desa Pakraman dalam Perspektif Pluralisme Hukum. Jurnal Magister Hukum Udayana (Udayana Master Law Journal), 3(3), h. 519.

${ }^{14}$ I Nengah Suastika. 2014. Urgensi Pendidikan Karakter Berlandaskan Tri Hita Karana (Studi Pengembangan Model Pembelajaran PKN-SD di Kota Singaraja). InSeminar Nasional Riset Inovatif (Vol. 2), h. 311.

15I Gusti A. A. Ariani, Ni Nyoman Sukerti, 2014, Eksistensi Otonomi Desa Pakraman di Bali dalam Kerangka Otonomi Daerah Khususnya dalam Pengelolaan Obyek Wisata. Jurnal Magister Hukum Udayana (Udayana Master Law Journal), 3(2), h. 337.

16 Wahyudi Arimbawa,I Komang Gede Santhyasa, 2017, Model Pengelolaan Obyek Wisata Peninggalan Sejarah Taman Ayun Berbasis Nilai Lokal. Seminar Nasional Space, h. 451. 
Luar Pura Taman Ayun telah mendapat delegasi dari pemerintah daerah kepada Puri Ageng Mengwi dan telah mempunyai kepastian hukum yang mengikat.

Kedua cara ini dapat dilakukan oleh Desa Pakraman sanur dengan pemerintah kota Denpasar dalam pemungutan retribusi masuk kawasan wisata. Pemerintah kota Denpasar dapat bekerjasama dengan Desa Pakraman sanur dalam melakukan pengelolaan yang dalam hal ini juga melakukan pemungutan retribusi masuk kawasan wisata yang ada di sanur. Terlebih lagi sanur yang merupakan kawasan pariwisata yang telah ditetapkan dalam Pasal 82 huruf c Peraturan Daerah Provinsi Bali No 16 Tahun 2009 tentang Rencana Tata Ruang Wilayah Provinsi Bali Tahun 2009-2029. Yang dimaksud dengan kawasan pariwisata berdasarkan Pasal 1 Angka 55 Kawasan Pariwisata merupakan sebuah kawasan strategis pariwisata yang ada dalam geografis satu atau lebih wilayah administrasi desa/kelurahan yang dimana di dalamnya terdapat suatu obyek wisata ataupun berpotensi besar yang dapat dijadikan sebuah daya tarik wisata, akses di segala bidang yang tinggi, terdapatnya fasilitas umum, fasilitas pariwisata, dan aktivitas sosial budaya masyarakat yang bersinergi saling mendukung dalam perwujudan kegiatan kepariwisataan. Dalam pelaksanaan pungutan retribusi tentunya dengan besaran retribusi yang telah ditentukan sebelumnya oleh pemerintah kota Denpasar. Seperti yang telah dilakukan oleh kabupaten Badung yang menetapkan tarif besaran retribusi tempat rekreasi melalui Peraturan Daerah Kabupaten Badung Nomor 25 Tahun 2011 Tentang Retribusi Tempat Rekreasi Dan Olahraga yang telah diubah melalui Peraturan Daerah Kabupaten Badung Nomor 6 Tahun 2016 Tentang Perubahan Atas Peraturan Daerah Kabupaten Badung Nomor 25 Tahun 2011 Tentang Retribusi Tempat Rekreasi Dan Olahraga. Begitu pula dengan kabupaten Gianyar yang telah menetapkan tarif besaran retribusi tempat rekreasi dan olahraga melalui Peraturan Daerah Kabupaten Gianyar Nomor 8 Tahun 2010 tentang Retribusi Tempat Rekreasi Dan Olahraga jo Peraturan Bupati Gianyar 129 tahun 2018 tentang Peninjauan Tarif Retribusi Tempat Rekreasi Dan Olahraga.

Melihat perbandingan dari pengelolaan Kawasan Luar Pura Taman Ayung yang telah didelegasikan kepala Puri Ageng Mengwi melalui Keputusan Bupati Badung No. 2038/02/HK/2012 Tentang Penetapan Pelaksana Pengelolaan ODTW Kawasan Luar Pura Taman Ayun di Kab. Badung Oleh Puri Ageng Mengwi serta di Kabupaten Tabanan yang telah melakukan kerja sama dengan Desa Pakraman ini dinilai sangat tepat untuk mengantisipasi pungutan retribusi masuk kawasan wisata oleh Desa Pakraman yang terindikasi sebagai pungutan liar (Pungli). Sehingga keberadaan payung hukum atau rgensinya disini sangat diperlukan oleh Desa Pakraman untuk dapat mengelola obyek pariwisata di desanya untuk dapat dimasukkan sebagai pendapatan desa.

\section{Kesimpulan}

Merujuk kepada uraian dari permasalahan diatas maka dapat disimpulkan sebuah kesimpulan dari penelitian ini adalah sebagai berikut, bahwa berpedoman pada UU pajak daerah dan retribusi daerah Nomor 28 Tahun 2009 telah diatur tentang pungutan masuk kawasan wisata dalam Pasal 127 huruf i, yang seharusnya dikelola oleh pemerintah daerah. Namun seperti apa yang telah terjadi di pantai sanur, bahwa pengelolaan tidak ada kejelasan bagi Desa Pakraman di Bali yang melakukan pungutan tersebut dengan tujuan untuk menambah pemasukan desa adat yang digunakan nantinya untuk kegiatan adat atau kegiatan keagamaan di Desa Pakraman.

Untuk menghindari adanya dugaan pungli oleh Desa Pakraman dalam melakukan pemungutan retribusi masuk kawasan desa yang ada di Desa Pakraman maka diperlukannya pengelolaan yang terpadu antara pemerintah daerah dan Desa Pakraman. 
Karena pemerintah daerah merupakan pihak yang berwenang secara peraturan perundangundangan untuk melakukan pungutan retribusi masuk kawasan wisata. Selama ini Desa Pakraman melakukan pungutan retribusi tersebut bukan untuk memperkaya diri sendiri, melainkan dijadikan pendapatan desa yang sebelumnya telah disepakati dengan perarem dalam Desa Pakraman. Dalam hal ini telah terdapat 2 model yang telah diterapkan oleh dua pemerintah daerah dalam melakukan pengelolaan obyek wisata dalam Desa Pakraman termasuk di dalamnya melakukan pungutan retribusi. Para Desa Pakraman yang masih sampai saat ini melakukan pungutan retribusi masuk kawasan wisata hendaknya mengikuti atau memilih model pengelolaan yang tentunya terlebih dahulu melakukan konsultasi atau mendiskusikannya lebih lanjut dengan pemerintah daerah. Demikian pula untuk pemerintah daerah agar melakukan perlindungan hukum kepada Desa Pakraman yang melakukan pungutan retribusi masuk kawasan wisata dan pendampingan sehingga tidak bertentangan maupun menimbulkan masalah dengan berbagai peraturan perundangundangan yang telah ada. Dimana nantinya diharapkan tidak ada lagi masalah serupa yang muncul di kemudian hari.

\section{Daftar Pustaka}

Buku

Marzuki, P. M. (2005). Penelitian Hukum, Jakarta: Kencana Prenada Media Group.

Windia, W. P. (2010). Bali mawacara: kesatuan awig-awig, hukum, dan pemerintahan di Bali. Denpasar: Udayana University Press.

Diantha, I. M. P. (2016). Metodologi penelitian hukum normatif dalam justifikasi teori hukum. Jakarta: Prenada Media.

\section{Jurnal}

Adharinali. (2012) Eksistensi Hukum Adat Dalam Penyelenggaraan Pemerintahan Desa Di Bali, Jurnal Rechts Vinding volume 1 nomor 3.

Adharinalti, A. (2012). Eksistensi Hukum Adat Dalam Penyelenggaraan Pemerintahan Desa Di Bali. Jurnal Rechts Vinding: Media Pembinaan Hukum Nasional, 1(3), 409-418.

Dewi, A. A. I. A. A., (2014) Eksistensi Otonomi Desa Pakraman dalam Perspektif Pluralisme Hukum. Jurnal Magister Hukum Udayana (Udayana Master Law Journal), 3(3). 515-528. https://doi.org/10.24843/JMHU.2014.v03.i03.p13

Suastika, I. N. (2014). Urgensi Pendidikan Karakter Berlandaskan Tri Hita Karana (Studi Pengembangan Model Pembelajaran PKN-SD di Kota Singaraja). InSeminar Nasional Riset Inovatif (Vol. 2). 308-314.

Gede Suacana I Wayan, (2016) Tantangan Dan Peluang Otonomi Desa Dalam Membangun Governance Desa Di Bali, Jurnal Ilmu Politik, 22(1).

Suatmaja, D. N. G. (2016). Peranan Majelis Desa Pakraman Bali Dalam Pelaksanaan Investasi Kepariwisataan Di Wilayah Desa Pakraman. Jurnal Magister Hukum Udayana (Udayana Master Law Journal), 5(2), 353-367. https:// doi.org/10.24843/JMHU.2016.v05.i02.p10

Ariani, I. G. A. A. (2014). Eksistensi Otonomi Desa Pakraman di Bali dalam Kerangka Otonomi Daerah Khususnya dalam Pengelolaan Obyek Wisata. Jurnal Magister Hukum Udayana (Udayana Master Law Journal), 3(2). 327-345.

Mulyono, S. P. (2014). Sinergitas Penyelenggaraan Pemerintahan Desa Pasca Pemberlakuan UU No. 6 Tahun 2014 Tentang Desa.Masalah-Masalah Hukum, 43(3), 438-444. https://doi.org/10.14710/mmh.43.3.2014.438-444

Sudantra, I. K., Astiti, T. I. P., \& Laksana, I. G. N. D. (2017). Sistem peradilan adat dalam kesatuan-kesatuan masyarakat hukum adat desa pakraman di Bali. Jurnal Kajian Bali (Journal of Bali Studies),7(1), 85-104. https://doi.org/10.24843/JKB.2017.v07.i01.p06 
Satrya, I. K. T. Y., Sinarwati, N. K., Herawati, N. T., \& AK, S. (2017). Sinergi Desa Adat dan Desa Dinas Dalam Pengelolaan Aset Desa Untuk Mewujudkan Harmonisasi (Studi Pada Desa Adat dan Desa Dinas Sambangan). JIMAT (Jurnal Ilmiah Mahasiswa Akuntansi) Undiksha, 7(1).

Arimbawa, W., \& Santhyasa, I. K. G. Model Pengelolaan Obyek Wisata Peninggalan Sejarah Taman Ayun Berbasis Nilai Lokal. Seminar Nasional Space, 444-458.

\section{Internet}

Supartika Putu. 2018. bali.tribunnews.com. Bendesa Sanur Kaja Beri Klarifikasi, yang Ditangkap di Pantai Matahari Terbit Bukan Pecalang, Retrieved from https:/ / bali.tribunnews.com/2018/11/07/bendesa-sanur-kaja-beri-klarifikasi-yangditangkap-di-pantai-matahari-terbit-bukan-pecalang 